ISSN 1392-3196 / e-ISSN 2335-8947

Zemdirbyste-Agriculture, vol. 105, No. 4 (2018), p. 339-348

DOI 10.13080/z-a.2018.105.043

\title{
Effects of cultivation technologies on woody biomass yield of various willow (Salix spp.) cultivars
}

\author{
Eugenija BAKŠIENĖ, Jelena TITOVA \\ Voke Branch, Lithuanian Research Centre for Agriculture and Forestry \\ Žalioji 2, Trakų Vokè, Vilnius, Lithuania \\ E-mail: jelena.titova@lammc.lt
}

\begin{abstract}
A strong interest in renewable energy is currently a world-wide trend. The European Union stresses the importance of the biomass application and diverse development opportunities and promotes the use of plant biomass as a renewable energy source. The short rotation energy plants, including willow and poplar are promising in this respect. This research aims to explore the changes in biomass dry matter yield and other biometric characteristics of three willow (Salix spp.) cultivars 'Tora', 'Tordis' and 'Gudrun' as influenced by nitrogen fertilization rates, cutting frequency, planting density and year of growing. A field trial was performed at the Vokè Branch of Lithuanian Research Centre for Agriculture and Forestry on a light textured soil, sandy loam Haplic Luvisol (LVha) in the climatic zone of south-eastern region of Lithuania during 2005-2014. In the spring of 2005, cuttings of willow were planted in rows at 0.65 and $0.50 \mathrm{~m}$ distances. Before planting, the entire field was fertilized once with mineral $\mathrm{P}_{60} \mathrm{~K}_{80}\left(60 \mathrm{~kg} \mathrm{ha}^{-1} \mathrm{P}_{2} \mathrm{O}_{5}, 80 \mathrm{~kg} \mathrm{ha}^{-1} \mathrm{~K}_{2} \mathrm{O}\right)$ rate. In May, when cuttings fully took roots, the following rates of nitrogen were applied once according to the experimental design: $\mathrm{N}_{0}$ (unfertilized), $\mathrm{N}_{30}\left(30 \mathrm{~kg} \mathrm{ha}^{-1} \mathrm{~N}\right), \mathrm{N}_{60}\left(60 \mathrm{~kg} \mathrm{ha}^{-1} \mathrm{~N}\right)$, $\mathrm{N}_{90}\left(90 \mathrm{~kg} \mathrm{ha}^{-1} \mathrm{~N}\right)$ and $\mathrm{N}_{120}\left(120 \mathrm{~kg} \mathrm{ha}^{-1} \mathrm{~N}\right)$. In 2006, 2012, 2013 and 2014 the plants were repeatedly fertilized. In early spring of 2006, part of the willows were cut, others were left to grow. Salix spp. cultivars 'Tora' and 'Tordis' produced higher biomass dry matter yields than 'Gudrun' $(p<0.05)$. The longest shoots were produced by 'Tora' and 'Tordis'. $\mathrm{N}_{90}$ and $\mathrm{N}_{120}$ fertilizer rates had the strongest impact on biomass dry matter yield of willows and increased biomass yield. Biomass dry matter yield of willows, cut after the first growing year (in spring 2006), was greater than that of not cut ones. Maximum biomass dry matter yield was produced in the plots, where willows had been planted in rows at a distance of $0.5 \mathrm{~m}$ between the plants.
\end{abstract}

Key words: biofuel, fertilization, 'Gudrun', 'Tora', 'Tordis'.

\section{Introduction}

The problem of environmental pollution, intensifying climate change, also unstable prices of fossil fuel and the growing demand for energy require search for alternative sources of energy. Fast growing short rotation woody crops represent a promising source of renewable energy and play a significant role in a more secure and sustainable energy future for the world (Keoleian, Volk, 2005; Hauptvogl, 2013; Njakou Djomo et al., 2013; Sevel et al., 2014). In the countries of the European Union, the idea that biomass is not only the food, feed, fibre, future industry, but also energy input gains increasing realization. This energy source can be seen as a local, mostly suitable for single households or small communities (Hanley, Karp, 2013; Hauptvogl, 2013; Njakou Djomo et al., 2015). Furthermore, it is considered that the use of biomass for energy does not increase emissions into the atmosphere of such greenhouse gas as carbon dioxide (Keoleian, Volk, 2005; Njakou Djomo et al., 2013; Cunniff et al., 2015).

In Lithuania, about $20 \%$ of the country's total farmland area is unproductive and of low productivity, where traditional farming is mostly unprofitable (The productivity...,2011; Lietuvos Respublikos žemès fondas, 2017; http://zis.lt/wp-content/uploads/2017/04/ZF_2017. pdf). Cultivation of bioenergy plants is more promising because they produce a stable and abundant biomass yield in a short time. Compared to traditional crops, they are usually more resistant to adverse environmental factors, including drought, frost, pests, diseases, and are tolerant of poor soil conditions (McKendry, 2002; Keoleian, Volk, 2005; Hangs et al., 2014; Richards et al., 2014; Njakou Djomo et al., 2015; Beauchamp et al., 2018). Bioenergy crops are perennial and able to regrow after cutting, that is, can grow many years in one place. This could save money for soil treatment, procurement of seeds and other inputs. They have also low cost, low energy inputs to produce biomass (Dimitriou, Aronsson, 2010; Njakou Djomo et al., 2013). In addition, growing of bioenergy crops reduces erosion process and leaching of useful chemicals from infertile soils (Šateikis, 2006; Demo et al., 2014; Phillips et al., 2014).

The most promising bioenergy plants include various species and cultivars of willow (Salix spp.). Belonging to the family Salicaceae Mirb., the genus 
Salix comprises about 450 species worldwide distributed mostly in the Northern Hemisphere (Kuzovkina, Quigley, 2005). Willows are tolerant of high planting densities and are able to reproduce fast and regrow after cutting some centimetres above the soil surface (Hauptvogl, 2013; Nordborg et al., 2018). Some cultivars of willow are fast growing, forming a large yield of wood and, most importantly, abundant dry matter yield. Willows are undemanding to soil (Beauchamp et al., 2018). Very low amounts of ash are produced during willow combustion (Hanley, Karp, 2013; Hytönen, Nurmi, 2015). About 19-20 MJ kg-1 of energy can be generated from the soft-wood willow species after the wood has dried out (Mészáros et al., 2007; Stolarski et al., 2015). Moreover, these plantations absorb considerable amounts of carbondioxide (Njakou Djomo et al., 2013).

Willows are recommended to be cut down every three to five years (Dimitriou, Aronsson, 2010; Stolarski et al., 2017). The estimated economic lifespan of a short rotation willow coppice stand is 20 to 25 years (Dimitriou, Aronsson, 2005; Dias et al., 2017).

Sweden is a leading country in the world that uses energy crops for thermal energy production (Dimitriou, Aronsson, 2010). Many willow hybrids, producing high biomass yields, have been developed there: 'Tora', 'Tordis', 'Olaf', 'Torhild', 'Gudrun', etc. Some willow cultivars are also grown in Lithuania (Bakšienè et al., 2012). These cultivars produce $5-15 \mathrm{t} \mathrm{ha}^{-1}$ of wood per year, which is suitable for combustion and thermal energy production (Adegbidi et al., 2001; Mirck et al., 2005; Aylott et al., 2008; Stolarski et al., 2008; Mola-Yudego, Gonzáles-Olabarria, 2010). However, there is still lack of research, how Swedish cultivars of willows perform in the climatic zone of south-eastern region of Lithuania, in light textured soils. Such research would help to identify energy plants, which are suitable for cultivation in Lithuania, to offer methodology for growing these plants in Lithuania. It would help to develop the use of renewable energy sources (plant biomass) in Lithuania and improve the environment.

This research aims to explore changes in biomass dry matter yield and other biometric characteristics of three willow (Salix spp.) cultivars 'Tora', 'Tordis' and 'Gudrun' as influenced by nitrogen fertilization rates, cutting frequency, planting density and year of growing. Such complex studies on light textured soils in south-eastern region of Lithuania have not been performed before.

\section{Materials and methods}

The study was performed at the Voke Branch of Lithuanian Research Centre for Agriculture and Forestry. Willow (Salix sp.) cultivars 'Tora', 'Tordis' and 'Gudrun' were studied. 'Tora' (Salix schwerinii $\times$ $S$. viminalis) is a cross between a Siberian basket willow and the cultivar 'Orm'. 'Tora' produces somewhat lower number of shoots than other willow cultivars, but they are long. 'Tordis' $(($ Salix schwerinii $\times S$. viminalis $) \times$ $S$. viminalis) is a cross between the cultivars 'Tora' and 'Ulv'. Both cultivars ('Tora' and 'Tordis') produce very large biomass dry matter yield in Sweden. It is expected that they will perform well in Lithuania as well. Both cultivars are resistant to the fungus Puccinia recondite. The cultivar 'Gudrun' (Salix dasyclados) is a hybrid between the Russian 'Helga' and the clone 'LångaVeka Röd' from Sweden. The cultivar has low moisture content in harvested wood. It is very resistant to the frost and leaf beetles (Chrysomelidae). The leaves of 'Gudrun' are wide. The density of shoots of 'Gudrun' is especially high (Hauptvogl, 2013; Aronsson et al., 2014). These willows were grown on light textured soil in the climatic zone of the south-eastern Lithuania $\left(54^{\circ} 37^{\prime} \mathrm{N}, 25^{\circ} 06^{\prime} \mathrm{E}\right)$ in $2005-$ 2014. According to agrochemical analyses, the soil of the experimental site is sandy loam Haplic Luvisol (LVha) according to WRB (2014). Agrochemical soil indicators: $\mathrm{pH}_{\mathrm{KCl}}$ 5.6-5.7, hydrolytic acidity - 2.9-3.8 mequiv $\mathrm{kg}^{-1}$, the amount of absorbed bases - 6.4-7.2 meq kg-1 of soil, of humus - 1.97-2.1\%, available phosphorus $\left(\mathrm{P}_{2} \mathrm{O}_{5}\right)-182 \mathrm{mg} \mathrm{kg}^{-1}$, available potassium $\left(\mathrm{K}_{2} \mathrm{O}\right)-167-$ $180 \mathrm{mg} \mathrm{kg}^{-1}$ of soil.

The willow trial comprised three factors. Factor A - Salix spp. cultivars: 'Tora', 'Tordis' and 'Gudrun'; factor B - fertilization rate: control (no fertilizers), $\mathrm{N}_{30} \mathrm{P}_{60} \mathrm{~K}_{80}\left(30 \mathrm{~kg} \mathrm{ha}^{-1} \mathrm{~N}, 60 \mathrm{~kg} \mathrm{ha}^{-1} \mathrm{P}_{2} \mathrm{O}_{5}, 80 \mathrm{~kg} \mathrm{ha}^{-1} \mathrm{~K}_{2} \mathrm{O}\right)$, $\mathrm{N}_{60}^{30} \mathrm{P}_{60} \mathrm{~K}_{80}\left(60 \mathrm{~kg} \mathrm{ha}^{-1} \mathrm{~N}, 60 \mathrm{~kg} \mathrm{ha}^{-1} \mathrm{P}_{2}^{2} \mathrm{O}_{5}, 80 \mathrm{~kg} \mathrm{ha}^{-1} \mathrm{~K}_{2}^{2} \mathrm{O}\right)$, $\mathrm{N}_{90}^{60} \mathrm{P}_{60}^{60} \mathrm{~K}_{80}^{80}\left(90 \mathrm{~kg} \mathrm{ha}^{-1} \mathrm{~N}, 60 \mathrm{~kg} \mathrm{ha}^{-1} \mathrm{P}_{2}^{2} \mathrm{O}_{5}, 80 \mathrm{~kg} \mathrm{ha}^{-1} \mathrm{~K}_{2}^{2} \mathrm{O}\right)$, $\mathrm{N}_{120} \mathrm{P}_{60} \mathrm{~K}_{80}\left(120 \mathrm{~kg} \mathrm{ha}^{-1} \mathrm{~N}, 60 \mathrm{~kg} \mathrm{ha}^{-1} \mathrm{P}_{2} \mathrm{O}_{5}, 80 \mathrm{~kg} \mathrm{ha}^{-1}\right.$ $\mathrm{K}_{2} \mathrm{O}$ ); factor $\mathrm{C}$ - spacing between plants in the rows: 0.65 and $0.50 \mathrm{~m}$. In 2008, a fourth factor was included - cutting of willows shoots after the first year of growth: cut and not cut.

The length of the experimental field was $10 \mathrm{~m}$, width $-4.5 \mathrm{~m}$, area $-45 \mathrm{~m}^{2}$. There were 72 fields, 4 replications were used. The cuttings (4,500 pieces, $20 \mathrm{~cm}$ in lent and 7-10 $\mathrm{mm}$ in diameter) of willows were planted in the spring of 2005. The inter-row spacing was $0.75 \mathrm{~m}$, the distances between plants in rows were 0.65 and $0.50 \mathrm{~m}$ and $1.5 \mathrm{~m}$ row spacing was left between the two rows of willows. Preceding crop was oilseed radish.

In the spring of 2005, before planting of cuttings of willow, the entire field was fertilized once with mineral $\mathrm{P}_{60} \mathrm{~K}_{80}\left(60 \mathrm{~kg} \mathrm{ha}^{-1} \mathrm{P}_{2} \mathrm{O}_{5}, 80 \mathrm{~kg} \mathrm{ha}^{-1} \mathrm{~K}_{2} \mathrm{O}\right)$ rate. In May, when cuttings fully took roots, the following rates of nitrogen were applied once according to the experimental design: $\mathrm{N}_{0}$ (unfertilized), $\mathrm{N}_{30}\left(30 \mathrm{~kg} \mathrm{ha}^{-1} \mathrm{~N}\right), \mathrm{N}_{60}\left(60 \mathrm{~kg} \mathrm{ha}^{-1}\right.$ $\mathrm{N}), \mathrm{N}_{90}\left(90 \mathrm{~kg} \mathrm{ha}^{-1} \mathrm{~N}\right)$ and $\mathrm{N}_{120}\left(120 \mathrm{~kg} \mathrm{ha}^{-1} \mathrm{~N}\right)$. In the second year (2006) the aforementioned fertilization was repeated. In 2012, 2013 and 2014 the willows were been fertilized only with mineral $\mathrm{N}_{90} \mathrm{P}_{60} \mathrm{~K}_{80}$ rate.

In 2005 , in $1.5 \mathrm{~m}$ row spacing mechanical control of weeds by cultivation of the soil was used. In $0.75 \mathrm{~m}$ row spacing mechanical control of weeds or spraying the herbicide Roundup (a.i. glyphosate) were employed. In the spring of the second year of willow growth $1.5 \mathrm{~m}$ row spacing was cultivated once.

In early spring of 2006 part of the willows were cut - leaving stumps of about $10 \mathrm{~cm}$ above the soil surface (shoots cut treatment), others were left to grow (shoots not cut treatment).

Natural biomass yield of willows was determined at the end of vegetation period (at the end of November) in 2005-2008 by weighing the cut individual six shrubs from each experimental field. In 2011 and 2014, three shrubs from each experimental field were weighed and the result was multiplied by two. All shoots of plant were measured and weighed individually. After that biomass dry matter yield $\left(\mathrm{t} \mathrm{ha}^{-1}\right)$ was determined.

In 2006, 2007, 2011 and 2014 biomass dry matter yield $\left(\mathrm{t} \mathrm{ha}^{-1}\right)$ was determined only for willows that had been cut in the spring of 2006. In 2008, biomass dry matter yield $\left(\mathrm{t} \mathrm{ha}^{-1}\right)$ and other parameters were determined for willows that had been cut in the spring of 2006 and 
for those that had been not cut. Other parameters were diameter of dominant shoots $(\mathrm{mm})$, diameter of other shoots $(\mathrm{mm})$, length of dominant shoots $(\mathrm{m})$ and length of other shoots $(\mathrm{m})$. Dominant shoots were significantly taller and thicker than other shoots, and therefore accounted for most part of the biomass yield. Other shoots were all remaining shoots.

According to the practice notes of willow growing (Tubby, Armstrong 2002), at the end of growing cycle (2008), four-year willows should have been cut for biofuel production, but there were no opportunities to do that. They were left to grow further and only in 2011 biomass dry matter yield of willows was determined. From 2008 to 2011 samples of biomass were not taken, measurements were not carried out. In 2011, all willow shoots were cut. In 2014, biomass dry matter yield of willows was analysed only in experimental fields, which had not been fertilized or fertilized with mineral $\mathrm{N}_{90} \mathrm{P}_{60} \mathrm{~K}_{80}$ rate.

Meteorological conditions of the trial period are presented in Figures 1 and 2.

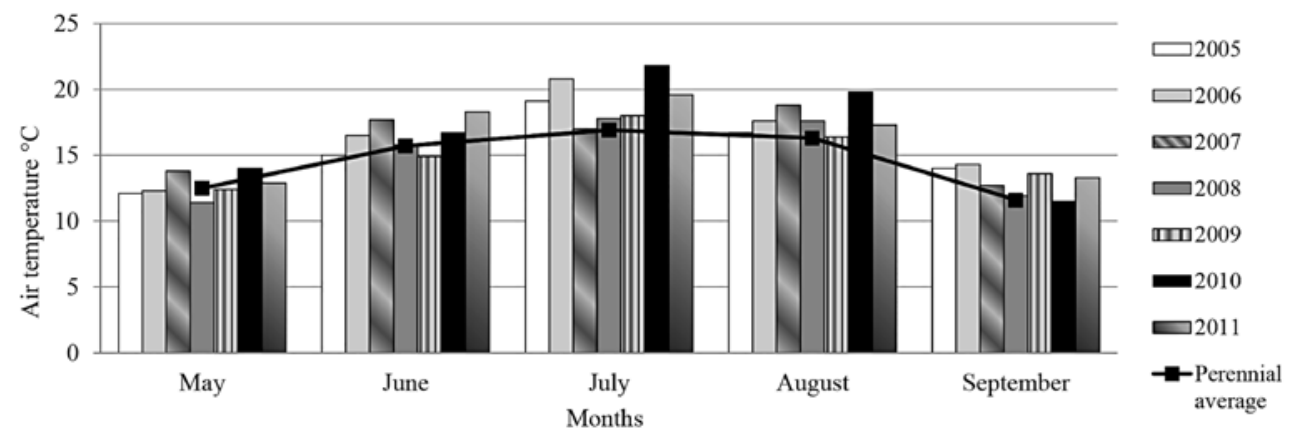

Figure 1. Air daily temperature data (average by month) of the Meteorological Station in Trakų Vokè, Vilnius, Lithuania

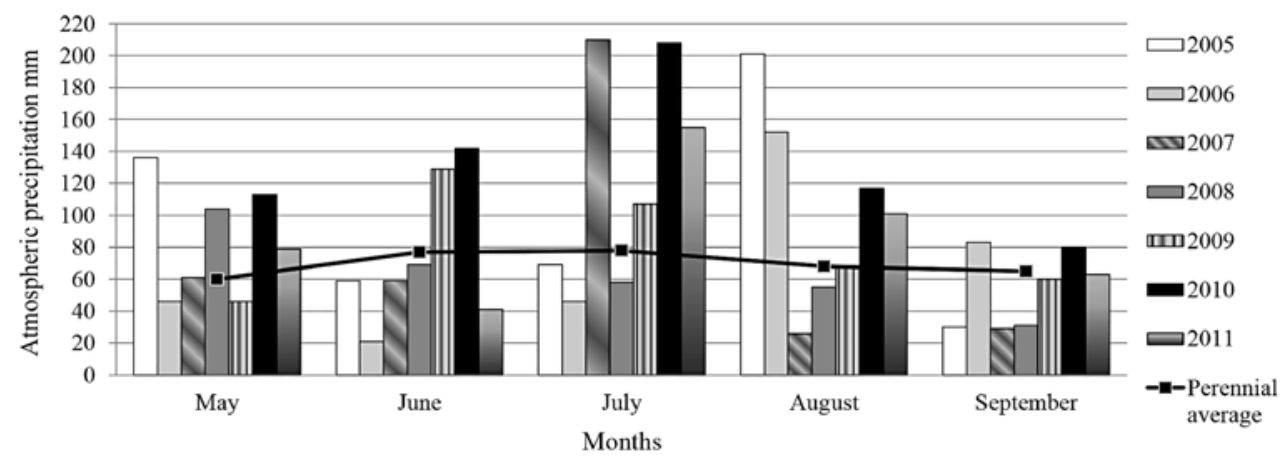

Figure 2. Atmospheric precipitation data (sum by month) of the Meteorological Station in Trakų Vokè, Vilnius, Lithuania

Data of biomass and production parameters from each treatment and four replications were processed using the analysis of variance (ANOVA) for Excel 2000, version 2.2 (Microsoft Corp., USA). The results of dry matter (DM) yield of willow biomass from 2005-2008 and 2011 were processed using a three-way analysis of variance. All other data were processed using a one-way analysis of variance (Raudonius, 2017). Fisher test was used for comparison of data (Clewer, Scarisbrick, 2001; Čekanavičius, Murauskas, 2003; 2004). Comparisons were done using $p<0.05$ and $p<0.01$ as significance levels.

\section{Results and discussion}

Dry matter yield of willow biomass. The study attempted to reveal the most important factors for obtaining the highest biomass yield of willow coppice. The 2005 data show that about $98.2 \%$ of the planted seedlings survived. Kuzovkina et al. (2018) also reported high mean survival rates of willows topping $90 \%$.

In 2005, meteorological conditions were favourable for the growth of willows. In May, average daily temperature was close to the standard climate norm $(\mathrm{SCN})\left(12.1^{\circ} \mathrm{C}\right)$, the amount of precipitation reached double norm $(136 \mathrm{~mm})$. It was enough heat and rainfall for willows during the summer. Only in September the amount of rainfall was much lower than the SCN $(30 \mathrm{~mm})$ (Figs 1 and 2).

Comparison of the biomass yield of different willow cultivars during the first year (2005) of growth revealed that the biomass dry matter yield of willows was significantly influenced by factor A - Salix spp. cultivars $\left(\mathrm{F}_{\text {fact. }}=27.85^{* *}\right)$, factor $\mathrm{B}-$ fertilization rate $\left(\mathrm{F}_{\text {fact. }}=3.83^{* *}\right)$ and factor $\mathrm{C}-$ distance between plants $\left(\mathrm{F}_{\text {fact. }}=5.47^{*}\right)$. Cultivars 'Tora' and 'Tordis' produced twice as high amount (2.2-3.5 $\left.\mathrm{t} \mathrm{ha}^{-1}\right)$ of biomass dry matter yield as 'Gudrun' $\left(1.0-2.5 \mathrm{t} \mathrm{ha}^{-1}\right)(p<0.05)$ (Table 1). Larsen et al. (2018) also reported that biomass dry matter yields of 'Tora' and 'Tordis' willows were among the highest of the investigated cultivars (all six growth years).

It was found that consistently increasing nitrogen fertilizer rates increased willow biomass yield of all cultivars accordingly: for 'Tora' from $2.2 \mathrm{t} \mathrm{ha}^{-1}$ (distance between plants $0.65 \mathrm{~m}$ ) and $2.4 \mathrm{tha}^{-1}$ (distance $0.50 \mathrm{~m}$ ) to $2.6 \mathrm{tha}^{-1}$ (distance $0.65 \mathrm{~m}$ ) and $3.3 \mathrm{tha}^{-1}$ (distance $0.50 \mathrm{~m}$ ), for 'Tordis' from 2.2 and $2.5 \mathrm{t} \mathrm{ha}^{-1}$ to 3.3 and $3.5 \mathrm{tha}^{-1}$, respectively, and for 'Gudrun' from $1.0 \mathrm{t} \mathrm{ha}^{-1}$ to 1.6 and 
Table 1. Average biomass dry matter yield $\left(\mathrm{t} \mathrm{ha}^{-1}\right)$ of willow cultivars at application of different rates of fertilizer (2005-2008 and 2011), when the shoots of the first year had been cut or not cut in spring 2006

\begin{tabular}{|c|c|c|c|c|c|c|c|c|c|c|c|c|}
\hline \multirow{3}{*}{$\begin{array}{c}\text { Fertilizer rate } \\
\mathrm{kg} \mathrm{ha}^{-1}\end{array}$} & \multicolumn{10}{|c|}{$\begin{array}{l}\text { Shoots cut } \\
\text { treatment }\end{array}$} & \multicolumn{2}{|c|}{$\begin{array}{c}\text { Shoots not cut } \\
\text { treatment }\end{array}$} \\
\hline & \multicolumn{12}{|c|}{ Year } \\
\hline & \multicolumn{2}{|c|}{2005} & \multicolumn{2}{|c|}{2006} & \multicolumn{2}{|c|}{2007} & \multicolumn{2}{|c|}{2008} & \multicolumn{2}{|c|}{2011} & \multicolumn{2}{|c|}{2008} \\
\hline \multicolumn{13}{|c|}{ Distance between plants $\mathrm{m}$} \\
\hline & 0.65 & 0.50 & 0.65 & 0.50 & 0.65 & 0.50 & 0.65 & 0.50 & 0.65 & 0.50 & 0.65 & 0.50 \\
\hline \multicolumn{13}{|c|}{ 'Tora' } \\
\hline $\mathrm{N}_{0}$ & 2.2 & 2.4 & 14.6 & 15.7 & 27.3 & 29.2 & 37.2 & 41.5 & 52.9 & 64.8 & 33.8 & 32.0 \\
\hline $\mathrm{N}_{30}^{0}$ & 2.4 & 2.5 & 15.6 & 16.1 & 29.4 & 30.0 & 41.8 & 43.2 & 68.8 & 81.5 & 37.0 & 35.3 \\
\hline $\mathrm{N}_{60}^{30}$ & 2.5 & 3.0 & 15.7 & 16.4 & 30.3 & 30.4 & 44.3 & 45.6 & 71.9 & 87.5 & 37.8 & 37.9 \\
\hline $\mathrm{N}_{90}$ & 2.5 & 3.1 & 16.6 & 16.8 & 30.3 & 31.3 & 45.0 & 46.8 & 76.0 & 104.4 & 39.3 & 38.5 \\
\hline $\mathrm{N}_{120}$ & 2.6 & 3.3 & 16.8 & 16.5 & 30.6 & 31.3 & 44.8 & 47.1 & 71.8 & 92.5 & 40.2 & 40.2 \\
\hline Average $^{1}$ & 2.4 & 2.9 & 15.9 & 16.3 & 29.6 & 30.4 & 42.6 & 44.8 & 68.3 & 86.1 & 37.6 & 36.8 \\
\hline \multicolumn{13}{|c|}{ 'Tordis' } \\
\hline $\mathrm{N}_{0}$ & 2.2 & 2.5 & 15.0 & 15.4 & 29.9 & 28.9 & 38.7 & 38.6 & 67.2 & 66.9 & 30.0 & 31.8 \\
\hline $\mathrm{N}_{30}^{0}$ & 2.4 & 2.9 & 15.2 & 16.4 & 29.7 & 30.8 & 40.0 & 42.3 & 68.9 & 80.6 & 34.9 & 34.1 \\
\hline $\mathrm{N}_{60}^{30}$ & 2.6 & 3.0 & 15.5 & 16.1 & 29.8 & 30.7 & 42.2 & 44.5 & 78.6 & 91.2 & 37.0 & 36.6 \\
\hline $\mathrm{N}_{90}^{60}$ & 3.0 & 3.2 & 16.4 & 16.6 & 31.5 & 31.0 & 45.4 & 43.5 & 96.0 & 103.2 & 37.5 & 38.7 \\
\hline $\mathrm{N}_{120}$ & 3.3 & 3.5 & 16.4 & 17.4 & 31.2 & 31.6 & 45.3 & 45.4 & 84.0 & 95.2 & 38.3 & 39.4 \\
\hline Average & 2.7 & 3.0 & 15.7 & 16.4 & 30.4 & 30.6 & 42.3 & 42.9 & 78.9 & 87.4 & 35.5 & 36.1 \\
\hline \multicolumn{13}{|c|}{ 'Gudrun' } \\
\hline $\mathrm{N}_{0}$ & 1.0 & 1.0 & 12.7 & 12.8 & 22.6 & 23.1 & 28.6 & 30.4 & 54.4 & 64.8 & 25.2 & 25.8 \\
\hline $\mathrm{N}_{30}^{0}$ & 1.4 & 1.3 & 13.0 & 13.5 & 23.2 & 23.6 & 29.4 & 31.9 & 57.4 & 72.5 & 27.8 & 26.3 \\
\hline $\mathrm{N}_{60}$ & 1.4 & 2.0 & 13.2 & 13.8 & 23.0 & 24.0 & 30.6 & 31.9 & 56.2 & 69.3 & 27.6 & 28.0 \\
\hline $\mathrm{N}_{90}$ & 1.5 & 2.5 & 13.6 & 14.2 & 24.1 & 24.2 & 33.1 & 32.8 & 54.9 & 52.0 & 28.8 & 30.6 \\
\hline $\mathrm{N}_{120}^{90}$ & 1.6 & 1.8 & 14.7 & 14.1 & 25.2 & 24.3 & 32.4 & 33.0 & 46.8 & 48.8 & 29.5 & 30.4 \\
\hline Average & 1.4 & 1.7 & 13.4 & 13.7 & 23.6 & 23.8 & 30.8 & 32.0 & 53.9 & 61.5 & 27.8 & 28.2 \\
\hline$\overline{\mathrm{F}_{\text {fact. }}}$ & \multirow{2}{*}{\multicolumn{4}{|c|}{$27.85 * *$}} & \multirow{2}{*}{\multicolumn{2}{|c|}{$128.97 * *$}} & \multirow{2}{*}{\multicolumn{2}{|c|}{$57.62 * *$}} & \multirow{2}{*}{\multicolumn{2}{|c|}{$24.65 * *$}} & \multirow{2}{*}{\multicolumn{2}{|c|}{$32.3 * *$}} \\
\hline Factor A & & & & & & & & & & & & \\
\hline Factor B & \multicolumn{2}{|c|}{$3.83 * *$} & \multicolumn{2}{|c|}{$2.68^{*}$} & \multicolumn{2}{|c|}{$4.03 * *$} & 3.9 & & 4.1 & & & $8 * *$ \\
\hline Factor $\mathrm{C}$ & 5.4 & & n & & & & $\mathrm{r}$ & & 13. & $9 * *$ & & \\
\hline Interaction $\mathrm{A} \times \mathrm{B}$ & $\mathrm{n}$ & & $\mathrm{n}$ & & & & $\mathrm{r}$ & & & & & \\
\hline Interaction $\mathrm{A} \times \mathrm{C}$ & $\mathrm{n}$ & & $\mathrm{n}$ & & & & & & & & & \\
\hline Interaction $\mathrm{B} \times \mathrm{C}$ & $\mathrm{n}$ & & $\mathrm{n}$ & & & & & & & & & \\
\hline Interaction $\mathrm{A} \times \mathrm{B} \times \mathrm{C}$ & $\mathrm{n}$ & & $\mathrm{n}$ & & & & $\mathrm{n}$ & & & & & \\
\hline $\mathrm{LSD}_{05}$ & & & & & & & & & & & & \\
\hline Cultivar (A) & 0.3 & & 0.8 & & & & 2.5 & & & & & \\
\hline Fertilization (B) & 0.4 & & 1.1 & & & & 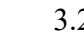 & & & & & 92 \\
\hline Distance between plants (C) & 0.3 & & 0.7 & & & & 2. & & & & & 19 \\
\hline Interaction $\mathrm{A} \times \mathrm{B}$ & 0.8 & & 1.9 & & & & 5.6 & & & & & \\
\hline Interaction $\mathrm{A} \times \mathrm{C}$ & 0.5 & & 1.2 & & & & 3. & & & & & 96 \\
\hline Interaction $\mathrm{B} \times \mathrm{C}$ & 0.5 & & 1.2 & & & & 3. & & & & & 96 \\
\hline Interaction $\mathrm{A} \times \mathrm{B} \times \mathrm{C}$ & 1.1 & & 2. & & & & & & 24 & & & 18 \\
\hline
\end{tabular}

${ }^{1}$ - average of willow biomass dry matter yield $\left(\mathrm{tha}^{-1}\right)$ of all fertilizer rates $\left(\mathrm{N}_{0}, \mathrm{~N}_{30}, \mathrm{~N}_{60}, \mathrm{~N}_{90}\right.$ and $\left.\mathrm{N}_{120}\right)$; *** - significant at the 0.05 and 0.01 probability levels, ns - non-significant differences

$2.5 \mathrm{t} \mathrm{ha}^{-1}$, respectively. Planting of willow cuttings at different distances also statistically significantly affected the production of dry matter biomass. Annual biomass of all tested willow cultivars was up to $0.1-1.2 \mathrm{t} \mathrm{ha}^{-1}$ higher when willows were planted densely, i.e. at $0.50 \mathrm{~m}$ distance $(p<0.05)$ (Table 1).

The most intense growth of all willows, which had been cut after the first growing year (in spring 2006), was recorded in the second (2006) year of cultivation. There was enough heat for willows in 2006. But willows lacked moisture in May $(46 \mathrm{~mm})$, in June $(21 \mathrm{~mm})$ and in July $(46 \mathrm{~mm})$. Willow leaves began to turn yellow. Aylott et al. (2008) and Miko et al. (2014) also noticed, that low precipitation can be identified as the principal limiting factor to crop yield. However, as willows have a sufficiently abundant, deep root system, they were able to use moisture from a deeper soil layer. Therefore, the drought damage to willows was less severe. In August, there was enough moisture, because the amount of rainfall was higher than the double norm of the SCN $(152 \mathrm{~mm})$.
In September, there was enough heat and moisture for intensive growth of willows $\left(14.3^{\circ} \mathrm{C}, 83 \mathrm{~mm}\right)$.

The results from the experimental year 2006 suggest that the biomass dry matter yield of willows was significantly influenced by the factor A - Salix spp. cultivars $\left(\mathrm{F}_{\text {fact. }}=24.06^{* *}\right)$ and factor $\mathrm{B}$ - fertilization rate $\left(\mathrm{F}_{\text {fact. }}=2.68^{*}\right)$. When the soil was fertilized with $\mathrm{N}_{90}$ and $\mathrm{N}_{120}$, biomass dry matter yield of willow cultivars 'Tora' and 'Tordis' planted at $0.65 \mathrm{~m}$ distance was by 2.0 and 2.2 and $1.4 \mathrm{t} \mathrm{ha}^{-1}$ higher than the average yield in the control, and in the case of $0.50 \mathrm{~m}$ distance - by 1.1 and 0.8 and 1.2 and $2.0 \mathrm{t} \mathrm{ha}^{-1}$ higher than the average yield in the control. In 2006, plants of 'Gudrun' produced lower biomass dry matter yield than 'Tora' and 'Tordis' (Table 1). Average dry matter yield of all investigated willow cultivars, fertilized with $\mathrm{N}_{90}$ and $\mathrm{N}_{120}$ rate, significantly differed $(p<0.05)$ from the unfertilized $\left(\mathrm{N}_{0}\right)$.

In 2007 and in 2008, the weather conditions were changeable, but for willows they were favourable, because during the third and the fourth growing years the 
willows grew intensively. Many fallen leaves prevented weed spread. Biomass yields of all willow cultivars doubled in 2007 in comparison with 2006. In 2007, maximum dry matter yield of 'Tora' was $31.3 \mathrm{t} \mathrm{ha}^{-1}$, of 'Tordis' - $31.5 \mathrm{t} \mathrm{ha}^{-1}$ and of 'Gudrun' - $25.2 \mathrm{t} \mathrm{ha}^{-1}$. In Hungary willows 'Tora' and 'Tordis' of the same age and, when the shoots of willows of the first year had been cut, produced maximum biomass dry matter yield of 46.6 and $39.6 \mathrm{t} \mathrm{ha}^{-1}$, respectively (Miko et al., 2014).

From 2006 to 2012 willows grew unfertilized, but the effect of fertilizers on biomass addition was observed. Probably, the developed affluent foliage turned into leaf litter and its mineralization enriched the soil with nutrients. Also willows fertilized with higher nitrogen rate (e.g., $\mathrm{N}_{90}$ and $\mathrm{N}_{120}$ ) grew and developed better, formed a better root system during the first year after planting; therefore, they were growing faster in subsequent years as well. Cunniff et al. (2015) also described the influence of below ground biomass on the above ground biomass yields of willows.

Similar experiments, conducted in Hungary, show that willow plantations can produce high amounts of biomass in the region with unfavourable conditions (low humus and nitrogen content in soil). The Swedish cultivars ('Tora', 'Tordis', etc.) used in the experiment produced high biomass dry matter yield.

Miko et al. (2014) studied three years old willow cultivars 'Tora' and 'Tordis', whose shoots, like in our study, had been cut after the first growing year. The authors reported that willows fertilized with $\mathrm{N}_{50}$ rate had significantly the highest biomass dry matter yield $(p<0.05)$. In Denmark willow cultivar 'Tordis' fertilized with $60 \mathrm{~kg} \mathrm{ha}^{-1} \mathrm{~N}$ rate had the highest biomass dry matter yield $(p<0.05)$. Higher doses did not lead to increased biomass production (Sevel et al., 2014). Our study showed that in $2007 \mathrm{~N}_{30}$ and $\mathrm{N}_{60}$ fertilizer rates did not induce production of higher yield of willows (compared to the control). Only after application of $\mathrm{N}_{90}$ and $\mathrm{N}_{120}$ rates, average dry matter yield of fertilized plants significantly differed from the control: cultivar 'Tora' - from 27.3 to $30.6 \mathrm{t} \mathrm{ha}^{-1}$ and from 29.2 to $31.3 \mathrm{t} \mathrm{ha}^{-1}$, cultivar 'Tordis' - from 29.9 to $31.5 \mathrm{t} \mathrm{ha}^{-1}$ and from 28.9 to $31.6 \mathrm{t} \mathrm{ha}^{-1}$, and 'Gudrun' - from 22.6 to $25.2 \mathrm{tha}^{-1}$, respectively $(p<0.05)$ (Table 1). In 2007, like in previous years, plants of the cultivar 'Gudrun' produced about 5-7 $\mathrm{t} \mathrm{ha}^{-1}$ lower $(p<0.05)$ dry matter yield than 'Tora' and 'Tordis'.

The results from the experimental year 2007 suggest that the biomass dry matter yield of willows was significantly influenced by the factor A - Salix spp. cultivars $\left(\mathrm{F}_{\mathrm{f} t \mathrm{f}}=128.97 * *\right)$ and factor $\mathrm{B}$ - fertilization rate $\left(\mathrm{F}_{\mathrm{fact}}=4.03 * *\right)$ (Table 1$)$.

The results from the experimental year 2008 suggest that the biomass dry matter yield of shoots cut treatment willows was significantly influenced by factor $\mathrm{A}-$ Salix spp. cultivars $(\mathrm{F}=57.62 * *)$ and factor $\mathrm{B}$ - fertilization rate $\left(\mathrm{F}_{\text {fact. }}=3.95^{* *}\right)$. In 2008 , the tested cultivars demonstrated different patterns of biomass yield formation, following the sequence: 'Tora' > 'Tordis' > 'Gudrun'. In 2008, willows of 'Tora' produced by $0.9-3.3 \mathrm{t} \mathrm{ha}^{-1}$ higher yield than 'Tordis' (Table 1 ). But the difference, like in 2006 and 2007, was not significant $(p>0.05)$. Biomass yield of 'Gudrun' was statistically significantly lower $(p<0.05)$ than that of 'Tora' and 'Tordis' (on average 11-12 $\mathrm{t} \mathrm{ha}^{-1}$ ).

Increased nitrogen fertilizer rates gradually increased biomass of all willow cultivars. Generally, plants fertilized with $\mathrm{N}_{60}, \mathrm{~N}_{90}$ and $\mathrm{N}_{120}$ rates produced significantly higher $(p<0.05)$ average biomass dry matter yield than unfertilized $\left(\mathrm{N}_{0}\right)$. The cultivar 'Tora' fertilized with $\mathrm{N}_{60}, \mathrm{~N}_{90}$ and $\mathrm{N}_{120}$ rates had 44.3-44.8 tha $\mathrm{t}^{-1}$ biomass dry matter yield, when the distance between plants was $0.65 \mathrm{~m}$, and 45.6-47.1 $\mathrm{t} \mathrm{ha}^{-1}$, when distance between plants was $0.50 \mathrm{~m}$. Cultivar 'Tordis' fertilized with the same rates had 42.2-45.4 $\mathrm{t} \mathrm{ha}^{-1}$ biomass dry matter yield (distance $0.65 \mathrm{~m}$ ) and $43.5-45.4 \mathrm{t} \mathrm{ha}^{-1}$ (distance $0.50 \mathrm{~m}$ ), respectively (Table 1). 'Gudrun' willows fertilized with $\mathrm{N}_{90}$ and $\mathrm{N}_{120}$ rates had statistically significantly higher biomass dry matter yield than unfertilized $\left(\mathrm{N}_{0}\right)$, when the distance between plants was $0.65 \mathrm{~m} .(p<0.05)$.

Regarding the willow planting density, it is evident that although planting at $0.65 \mathrm{~m}$ distance saves cuttings, but planting at $0.5 \mathrm{~m}$ distance results in higher biomass yield, presumably due to a larger number of plants in the same area. When willow cuttings had been planted at $0.50 \mathrm{~m}$ distance, the biomass yield in the fourth year (2008) was by 1.3-4.3 $\mathrm{t} \mathrm{ha}^{-1}$ higher than biomass yield, when willows cuttings had been planted at $0.65 \mathrm{~m}$ distance. However, this difference was not statistically significant $(p>0.05)$.

At the end of the first cycle of growing of willows for biofuel (four years after their planting) it became evident that willows grown for biofuel should be cut after the first growing year. Other authors confirm this fact too (Miko et al., 2014). Biomass dry matter yield of shoots not cut treatment willows in the fourth year was by 1.6-9.5 $\mathrm{t} \mathrm{ha}^{-1}$ lower compared to willows that had been cut during the first year in shoots cut treatment (Table 1). When analysing the yield of different willow cultivars, it can be said that biomass yield of 'Tora' ranged from 32.0 to $40.2 \mathrm{t} \mathrm{ha}^{-1}$, and biomass yield of 'Tordis' from 30.0 to $39.4 \mathrm{t} \mathrm{ha}^{-1}$. Biomass dry matter yield of 'Gudrun' willows was by $6.2-10.7 \mathrm{t} \mathrm{ha}^{-1}$ lower than that of 'Tora' and by $8-9.4$ t ha $^{-1}$ lower than that of 'Tordis' $(p<0.05)$ (Table 1).

The results from experimental year 2008 suggest that the biomass dry matter yield of shoots not cut treatment was significantly influenced by factor A - Salix spp. cultivars $\left(\mathrm{F}_{\text {fact. }}=32.3^{* *}\right)$ and factor $\mathrm{B}-$ fertilization rate $\left(\mathrm{F}_{\text {fact. }}=5.38^{* *}\right)$. In 2008 , average biomass dry matter yield of willows, not cut after the first year of growth, was almost always increasing with the increasing fertilizer rates. Generally, willow cultivars fertilized with $\mathrm{N}_{60}$, $\mathrm{N}_{90}$ and $\mathrm{N}_{120}$ rates had average dry matter yield, which significantly differed $(p<0.05)$ from the control (Table 1). Significant differences between biomass yield values of fertilized and non-fertilized willow cultivars 'Tora' and 'Tordis' were determined, when willows were fertilized with $\mathrm{N}_{60}, \mathrm{~N}_{90}$ and $\mathrm{N}_{120}$ rates. Biomass dry matter yield of 'Gudrun' willows planted at $0.65 \mathrm{~m}$ distance and fertilized with $\mathrm{N}_{120}$ rate was significantly higher $(p<0.05)$ than unfertilized willows. 'Gudrun' willows fertilized with $\mathrm{N}_{90}$ and $\mathrm{N}_{120}$ rates had significantly higher yield than unfertilised willows, when it were planted at $0.50 \mathrm{~m}$ distance between plants $\mathrm{N}_{120}(p<0.05)$. When shoots not cut treatment willow cuttings had been planted at $0.50 \mathrm{~m}$ distance, the average biomass yield in the fourth year (2008) was by only $0.06 \mathrm{t} \mathrm{ha}^{-1}$ higher than that of willows planted at $0.65 \mathrm{~m}$ distance $(p>0.05)$ (Table 1).

At the end of 2008 there were no facilities to cut willows, so the plants were left to grow. Consequently, there was the possibility to observe the willow development after the end of the recommended rotation period (four years). In 2009, 2010 and 2011 there was 
enough heat and precipitation for willows during the vegetation period. Average daily temperature by month and sum of atmospheric precipitation by month were similar to the standard climate norm or higher.

The survey showed that in 2011 the effect of planting distances $(0.65$ and $0.50 \mathrm{~m})$ still had significant impact on the biomass yield. In 2011, willow cultivars planted at $0.50 \mathrm{~m}$ distance produced by $2.0-28.4 \mathrm{t} \mathrm{ha}^{-1}$ higher biomass than willows planted at $0.65 \mathrm{~m}$ distance $(p<0.05)$ (Table 1). Njakou Djomo et al. (2015) and Castaño-Díaz at al. (2018) reported that there was no significant correlation between planting density and willow biomass yield, and biomass dry matter yield were not particularly sensitive to initial planting densities. However, planting densities need to be considered in the context of entire production system since other management decisions and cost, such as weed control and harvesting efficiency, will be affected (Keoleian, Volk, 2005).

Results of the experiment suggest that the biomass dry matter yield of willows was significantly influenced by factor $\mathrm{A}-$ Salix spp. cultivars $\left(\mathrm{F}_{\text {fact. }}=\right.$ $\left.24.65^{* *}\right)$, factor $\mathrm{B}-$ fertilization rate $\left(\mathrm{F}_{\text {fact. }}=4.15^{* *}\right)$, factor $\mathrm{C}$ - distance between plants $\left(\mathrm{F}_{\text {fact. }}=13.29 * *\right)$ and interaction $\mathrm{A} \times \mathrm{B}\left(\mathrm{F}_{\text {fact. }}=2.73^{*}\right)$ (Table 1$)$.
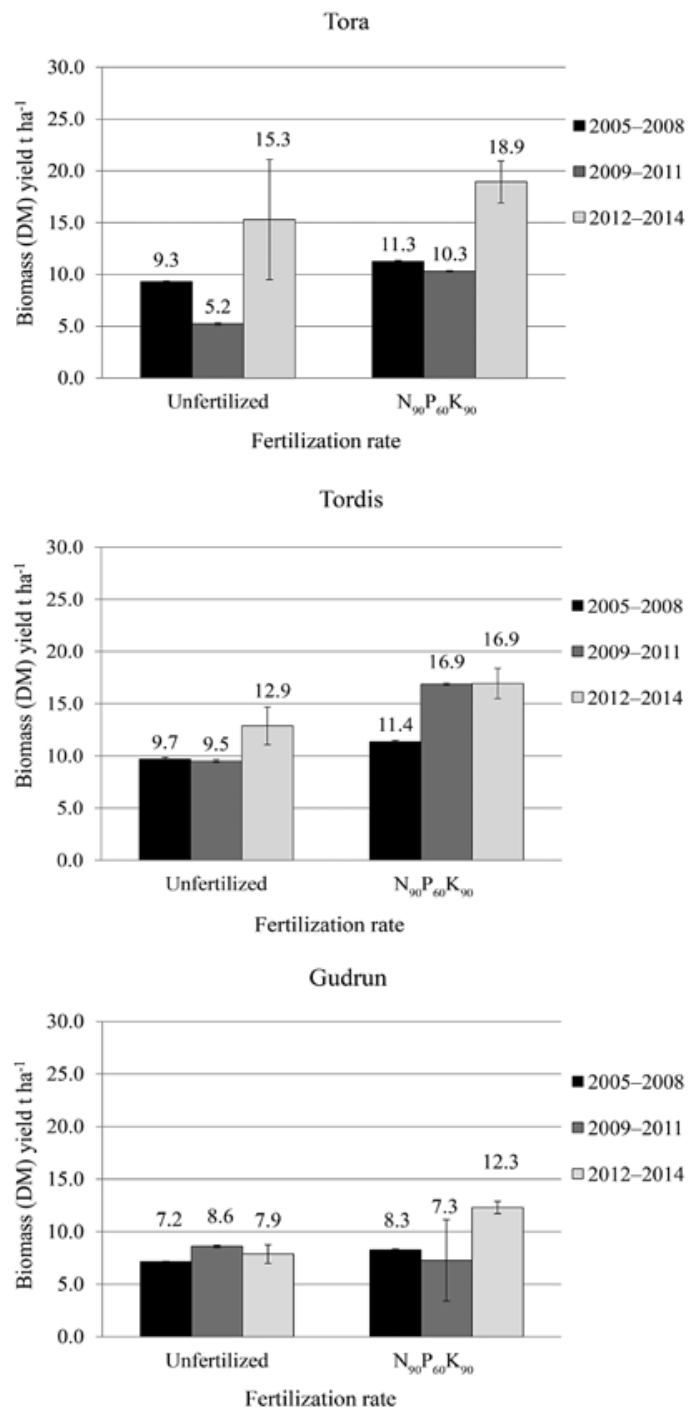

Mean value $\pm \mathrm{SE}$
In 2011, average biomass dry matter yield of cultivars 'Tora' and 'Tordis' fertilized with $\mathrm{N}_{60}, \mathrm{~N}_{90}$ and $\mathrm{N}_{120}$ rates significantly differed from the control. Higher biomass yield of 'Tora' and 'Tordis' (76.0-104.4 and 96.0 $103.2 \mathrm{t} \mathrm{ha}^{-1}$, respectively) was obtained when $\mathrm{N}_{90}$ fertilizer rate had been used. Biomass dry matter yield of 'Gudrun' willows in 2011 was statistically significantly independent of the application of mineral fertilizers. However, 'Gudrun' grew better applied with $\mathrm{N}_{30}$ and $\mathrm{N}_{60}$ rates.

Aylott et al. (2008) reported that mean annual biomass dry matter yield of willow cultivar 'Tora' was $9.3 \mathrm{t} \mathrm{ha}^{-1}$ per $1^{\text {st }}$ rotation, and $13.3 \mathrm{t} \mathrm{ha}^{-1}-$ per $2^{\text {nd }}$ rotation in United Kingdom. Sevel et al. (2014) found that mean annual biomass dry matter yield of 'Tordis' was $11.9 \mathrm{t} \mathrm{ha}^{-1}$ per first two growing years (the $1^{\text {st }}$ rotation) in Denmark. Larsen et al. (2016) reported that mean annual biomass dry matter yield of 'Tordis' per first three growing years (the $1^{\text {st }}$ rotation) was only 4-7 $\mathrm{t} \mathrm{ha}^{-1}$ and 7-10 $\mathrm{tha}^{-1}$ per 4-5 growing years (the $2^{\text {nd }}$ rotation) in Denmark. Results of ours research showed that at the age of 5-7 years (2009-2011) and at the age of 8-10 years (2012-2014) willows were still intensively growing: their biomass dry matter yield was the same or higher, compared with the first four years of growing (2005-2008) (Fig. 3). Mean
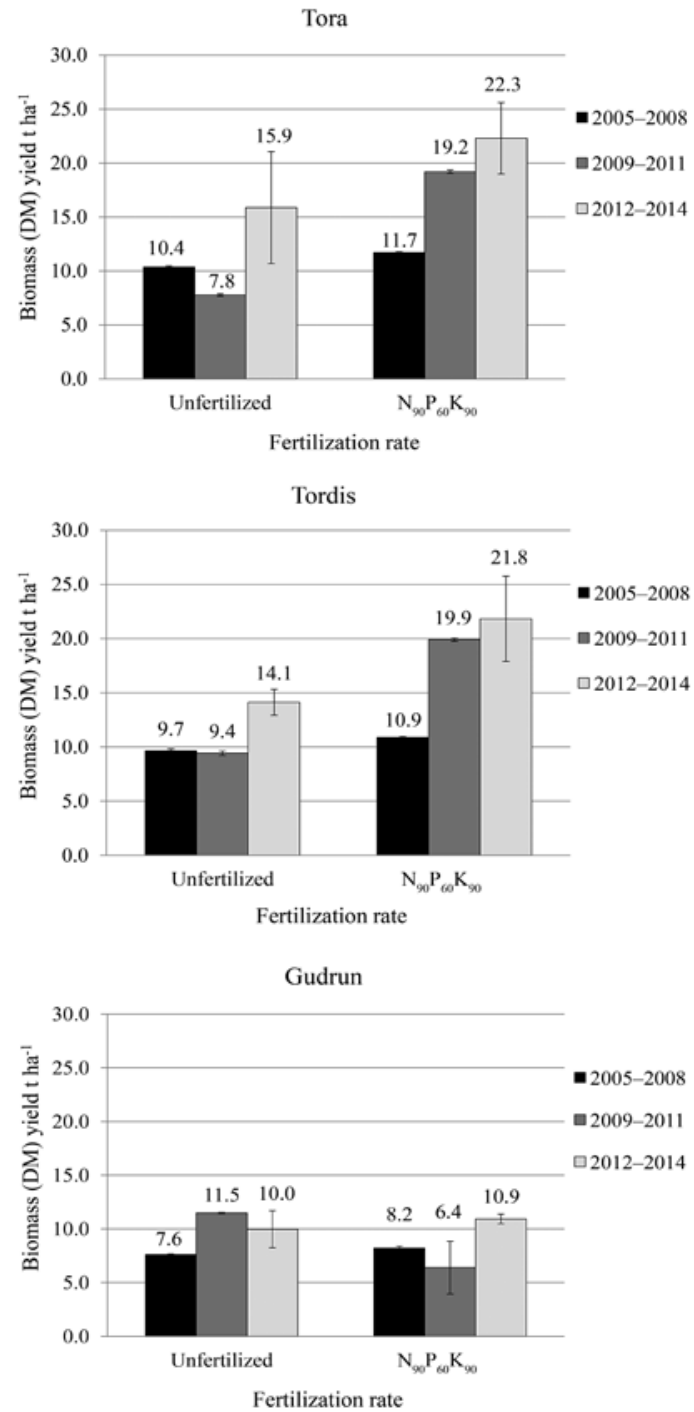

Figure 3. Mean annual biomass dry matter (DM) yield of cultivars of willows planted at 0.65 (left) and 0.50 (right) $\mathrm{m}$ distances between plants (unfertilized and fertilized) per growing periods (2005-2008, 2009-2011 and 2012-2014) 
annual biomass dry matter yield of the 'Tora' willow per $1^{\text {st }}$ rotation (2005-2008) was $10.9 \mathrm{t} \mathrm{ha}^{-1}$, of the 'Tordis' $10.7 \mathrm{t} \mathrm{ha}^{-1}$ and of the 'Gudrun' - $7.9 \mathrm{t} \mathrm{ha}^{-1}$. Mean annual biomass dry matter yield of the 'Tora' willow per $2^{\text {nd }}$ rotation (2009-2011) was $11.2 \mathrm{t} \mathrm{ha}^{-1}$, of the 'Tordis' $13.5 \mathrm{t} \mathrm{ha}^{-1}$ and of the 'Gudrun' $-8.8 \mathrm{t} \mathrm{ha}^{-1}$. Mean annual biomass dry matter yield of the 'Tora' willow per $3^{\text {rd }}$ rotation (2012-2014) was $18.1 \mathrm{t} \mathrm{ha}^{-1}$, of the 'Tordis' $16.4 \mathrm{t} \mathrm{ha}^{-1}$ and of the 'Gudrun'- $10.3 \mathrm{tha}^{-1}$. Stolarski et al. (2017) also did not find willow yield decrease with the plantation ageing (during the first ten years).

Results of ours research showed also that per $2^{\text {nd }}(2009-2011)$ and $3^{\text {rd }}(2012-2014)$ rotation unfertilized and fertilized with $\mathrm{N}_{90} \mathrm{P}_{60} \mathrm{~K}_{80}$ willows were still intensively growing (Fig. 3). In 2014, biomass dry matter yield of the cultivar 'Tora' was $46.0-56.8 \mathrm{tha}^{-1}$, of the 'Tordis'-38.6-50.8 $\mathrm{tha}^{-1}$ and of the 'Gudrun'-23.6$37 \mathrm{t} \mathrm{ha}^{-1}$ (0.65 $\mathrm{m}$ distance between plants) and 47.6-66.9, 42.4-65.5 and 29.9-32.8 $\mathrm{t} \mathrm{ha}^{-1}$, respectively $(0.50 \mathrm{~m}$ distance between plants). In 2014, willows fertilized with $\mathrm{N}_{90} \mathrm{P}_{60} \mathrm{~K}_{80}$ produced larger biomass dry matter yield than unfertilized willows $(p<0.05)$.

Biometric characteristics of willows. In 2006, cut willows developed 4-6 times more shoots than in the first year after planting (in 2005). During 2006, an average number of shoots of one plant was 8-12, and some plants produced 15 or even 19 shoots that very well suppressed weeds, grew really fast and produced significantly more wood. In 2005, nitrogen fertilization had a tendency to increase the number of shoots of one plant from 1.9-2.7 to 2.0-3.3. In 2006, nitrogen fertilization increased the number of shoots from 9.7-11.0 to $10.7-12.5$, but the impact was insignificant $(p>0.05)$. Demo et al. (2014) reported that in Slovakia the density of willow shoots significantly affected the length and diameter of the shoots. Also our research results showed that shoots of uncut plants were thicker and taller, but the willows were not forming shrubs, the number of their shoots was the same as in the first year after planting.

Data of stem diameter and height of the shoots cut and shoots not cut treatments willows in 2008 are presented in Tables 2 and 3.

In the plots, where willows had been cut after the first year (shoots cut willows), plants grew large and tall. The diameter of both dominant and other shoots depended little on their planting density and fertilization with different rates of nitrogen fertilizers (Table 2). It fluctuated in cultivar 'Tora' within the error range reaching 30-34 and 20-24 mm. The diameter of 'Tordis' dominant shoots was 2-6 mm larger than that of 'Tora', and of other shoots - very similar to 'Tora' (19-24 mm). The diameter of dominant shoots of cultivar 'Gudrun' was by 1-5 $\mathrm{mm}$ larger than that of 'Tora', while diameter of other shoots was similar to that of 'Tora' (20-24 mm).

Table 2. Biometric characteristics of three-year-old willow cultivars in 2008, when the shoots of the first year had been cut in spring 2006

\begin{tabular}{|c|c|c|c|c|c|c|c|c|}
\hline \multirow{2}{*}{$\begin{array}{c}\text { Fertilizer rate } \\
\mathrm{kg} \mathrm{ha}^{-1} \\
\end{array}$} & \multicolumn{4}{|c|}{ Diameter of shoots $\mathrm{mm}$} & \multicolumn{4}{|c|}{ Length of shoots $\mathrm{m}$} \\
\hline & \multicolumn{2}{|c|}{ dominant } & \multicolumn{2}{|c|}{ other } & \multicolumn{2}{|c|}{ dominant } & \multicolumn{2}{|c|}{ other } \\
\hline \multicolumn{9}{|c|}{ Distance between plants $m$} \\
\hline & 0.65 & 0.50 & 0.65 & 0.50 & 0.65 & 0.50 & 0.65 & 0.50 \\
\hline \multicolumn{9}{|c|}{ 'Tora' } \\
\hline $\mathrm{N}_{0}$ & 34 & 32 & 22 & 20 & 6.21 & 5.95 & 4.53 & 4.28 \\
\hline $\mathrm{N}_{30}^{0}$ & 33 & 32 & 23 & 22 & 6.42 & 6.00 & 4.67 & 4.45 \\
\hline $\mathrm{N}_{60}^{30}$ & 33 & 30 & 23 & 22 & 6.47 & 6.32 & 5.02 & 4.70 \\
\hline $\mathrm{N}_{90}^{60}$ & 34 & 32 & 24 & 20 & 6.71 & 6.70 & 5.29 & 4.83 \\
\hline $\mathrm{N}_{120}$ & 33 & 32 & 24 & 23 & 6.28 & 6.35 & 4.93 & 4.90 \\
\hline $\mathrm{LSD}_{05}$ & 1.3 & 2.2 & 2.2 & 3.3 & 0.457 & 0.398 & 0.692 & 0.533 \\
\hline \multicolumn{9}{|c|}{ 'Tordis' } \\
\hline $\mathrm{N}_{0}$ & 38 & 38 & 21 & 19 & 6.10 & 5.95 & 4.75 & 4.60 \\
\hline $\mathrm{N}_{30}^{0}$ & 36 & 35 & 22 & 22 & 6.29 & 6.30 & 5.11 & 4.95 \\
\hline $\mathrm{N}_{60}^{30}$ & 36 & 35 & 22 & 23 & 6.37 & 6.25 & 5.44 & 5.05 \\
\hline $\mathrm{N}_{90}^{60}$ & 34 & 34 & 23 & 23 & 6.37 & 6.44 & 5.17 & 5.15 \\
\hline $\mathrm{N}_{120}$ & 32 & 34 & 24 & 24 & 6.36 & 6.40 & 5.10 & 5.15 \\
\hline $\mathrm{LSD}_{05}$ & 6.5 & 4.5 & 3.3 & 5.6 & 0.252 & 0.449 & 0.371 & 0.413 \\
\hline \multicolumn{9}{|c|}{ 'Gudrun' } \\
\hline $\mathrm{N}_{0}$ & 35 & 34 & 21 & 20 & 5.11 & 4.85 & 3.89 & 4.05 \\
\hline $\mathrm{N}_{30}^{0}$ & 37 & 34 & 23 & 21 & 5.33 & 5.15 & 4.00 & 4.08 \\
\hline $\mathrm{N}_{60}^{30}$ & 35 & 35 & 24 & 22 & 5.29 & 5.18 & 4.06 & 3.95 \\
\hline $\mathrm{N}_{90}^{60}$ & 35 & 37 & 24 & 23 & 5.18 & 5.20 & 4.11 & 4.10 \\
\hline $\mathrm{N}_{120}^{90}$ & 35 & 35 & 24 & 24 & 5.09 & 5.00 & 4.15 & 4.10 \\
\hline $\mathrm{LSD}_{05}$ & 2.3 & 3.4 & 3.4 & 4.1 & 0.166 & 0.324 & 0.219 & 0.131 \\
\hline
\end{tabular}

The willows in shoots not cut treatment developed only 2-3 shoots, but they were by $4-14 \mathrm{~mm}$ thicker than in the shoots cut treatment. Shoots of shoots not cut treatment cultivars 'Tora' and 'Tordis' willows were by 5-16 and 1-10 mm thicker than shoots of shoots cut treatment (Table 3). Diameter of some shoots reached 36-45 ('Tora'), 33-39 ('Tordis') and 29-38 ('Gudrun') $\mathrm{mm}$. Diameters of shoots were by a few millimetres larger in less densely $(0.65 \mathrm{~m})$ planted coppice. Nitrogen fertilizer rates had no effect on shoot diameter.
Shoot length measurements in shoots cut treatment showed that the longest dominant and other shoots were those of willows cultivars 'Tora' (5.95-6.71 and 4.28-5.29 m) and 'Tordis' (5.95-6.44 and 4.6$5.44 \mathrm{~m}$ ), while shoots of 'Gudrun' (4.85-5.33 and 3.89$4.15 \mathrm{~m})$ were significantly shorter $(p<0.05)$ (Table 2$)$. Cultivar 'Gudrun' willows that had been cut after the first year grew by $0.64-1.53 \mathrm{~m}$ shorter when planted at $0.65 \mathrm{~m}$ distance and by $0.23-1.50 \mathrm{~m}$ shorter when planted at $0.5 \mathrm{~m}$ distancs, compared with plants of other cultivars. 
Table 3. Biometric characteristics of three-year-old willow cultivars in 2008, when the shoots of the first year had been not cut in spring 2006

\begin{tabular}{|c|c|c|c|c|c|c|c|c|}
\hline \multirow{2}{*}{$\begin{array}{l}\text { Fertilizer rate } \\
\mathrm{kg} \mathrm{ha}^{-1}\end{array}$} & \multicolumn{4}{|c|}{ Diameter of shoots $\mathrm{mm}$} & \multicolumn{4}{|c|}{ Length of shoots $\mathrm{m}$} \\
\hline & \multicolumn{2}{|c|}{ dominant } & \multicolumn{2}{|c|}{ other } & \multicolumn{2}{|c|}{ dominant } & \multicolumn{2}{|c|}{ other } \\
\hline \multicolumn{9}{|c|}{ Distance between plants $\mathrm{m}$} \\
\hline & 0.65 & 0.50 & 0.65 & 0.50 & 0.65 & 0.50 & 0.65 & 0.50 \\
\hline \multicolumn{9}{|c|}{ 'Tora' } \\
\hline $\mathrm{N}_{0}$ & 39 & 37 & 31 & 29 & 4.81 & 4.96 & 4.08 & 4.10 \\
\hline $\mathrm{N}_{30}^{0}$ & 43 & 40 & 32 & 34 & 4.98 & 5.08 & 4.34 & 4.28 \\
\hline $\mathrm{N}_{60}^{30}$ & 44 & 41 & 36 & 35 & 5.36 & 5.32 & 4.41 & 4.35 \\
\hline $\mathrm{N}_{90}^{60}$ & 44 & 39 & 37 & 36 & 5.95 & 5.44 & 4.46 & 4.30 \\
\hline $\mathrm{N}_{120}$ & 45 & 42 & 36 & 36 & 5.75 & 5.40 & 4.55 & 4.40 \\
\hline $\mathrm{LSD}_{05}$ & 6.5 & 5.8 & 6.6 & 7.2 & 0.488 & 0.433 & 0.364 & 0.247 \\
\hline \multicolumn{9}{|c|}{ 'Tordis' } \\
\hline $\mathrm{N}_{0}$ & 37 & 36 & 30 & 29 & 4.68 & 4.40 & 3.91 & 3.85 \\
\hline $\mathrm{N}_{30}^{0}$ & 37 & 38 & 31 & 32 & 4.95 & 4.62 & 4.18 & 3.95 \\
\hline $\mathrm{N}_{60}^{30}$ & 39 & 36 & 32 & 32 & 5.17 & 4.80 & 4.40 & 4.15 \\
\hline $\mathrm{N}_{90}^{60}$ & 37 & 38 & 33 & 33 & 5.20 & 4.96 & 4.41 & 4.20 \\
\hline $\mathrm{N}_{120}$ & 37 & 37 & 33 & 32 & 5.32 & 5.05 & 4.42 & 4.20 \\
\hline $\mathrm{LSD}_{05}$ & 2.2 & 2.6 & 3.7 & 4.4 & 0.489 & 0.50 & 0.446 & 0.341 \\
\hline \multicolumn{9}{|c|}{ 'Gudrun' } \\
\hline $\mathrm{N}_{0}$ & 32 & 32 & 27 & 25 & 3.96 & 4.05 & 3.67 & 3.55 \\
\hline $\mathrm{N}_{30}^{0}$ & 33 & 33 & 27 & 26 & 4.31 & 4.20 & 3.66 & 3.60 \\
\hline $\mathrm{N}_{60}^{30}$ & 35 & 34 & 28 & 26 & 4.23 & 4.15 & 3.68 & 3.65 \\
\hline $\mathrm{N}_{90}^{60}$ & 38 & 36 & 33 & 29 & 4.38 & 4.45 & 3.90 & 3.65 \\
\hline $\mathrm{N}_{120}$ & 37 & 36 & 32 & 28 & 4.42 & 4.40 & 3.85 & 3.70 \\
\hline $\mathrm{LSD}_{05}$ & 6.5 & 4.9 & 6.1 & 4.3 & 0.402 & 0.311 & 0.189 & 0.204 \\
\hline
\end{tabular}

Nitrogen fertilization $\mathrm{N}_{90}$ and $\mathrm{N}_{120}$ had significant impact $(p<0.05)$ on the length of shoots of 'Tora'. Shoots of 'Tordis' were longer, when the soil was fertilized with $\mathrm{N}_{60}, \mathrm{~N}_{90}$ and $\mathrm{N}_{120}$ rates, shoots of 'Gudrun' - with $\mathrm{N}_{30}$ $\mathrm{N}_{120}$ rates $(p<0.05)$.

In uncut willow coppice in shoots not cut treatment, shoots were by $0.17-1.68 \mathrm{~m}$ shorter than in the coppice that had been cut after the first year (Tables 2 and 3 ). Length of dominant shoots was $4.81-5.95 \mathrm{~m}$ of 'Tora', 4.4-5.32 m - of 'Tordis', and of the other shoots - 4.08$4.55 \mathrm{~m}$ of 'Tora', 3.85-4.42 m - of 'Tordis' (Table 3). Shoots of 'Gudrun' willows were by $0.41-1.57 \mathrm{~m}$ shorter than those of 'Tora' and by $0.24-0.94 \mathrm{~m}$ shorter than those of 'Tordis'. Shoots of shoots not cut treatment cultivars 'Tora' and 'Tordis' willows were significantly longer $(p<0.05)$ in the treatments fertilized with $\mathrm{N}_{60}$, $\mathrm{N}_{90}$ and $\mathrm{N}_{120}$ rates, shoots of 'Gudrun' - with $\mathrm{N}_{90}$ and $\mathrm{N}_{120}$ rates. Sevel et al. (2014) also reported the influence of nitrogen fertilization on the length of willow shoots.

Our studies showed that the tested willow cultivars demonstrated different patterns of growth, development and formation of biomass yield, following the sequence: 'Tora' $>$ 'Tordis' $>$ 'Gudrun'. It was determined that cultivation of willows for more than four years results in their rather intense growth, but the harvesting becomes even more complicated because the willow shoots become very thick.

\section{Conclusions}

1. Plants of willow cultivars 'Tora' and 'Tordis' produced higher biomass dry matter yields and longer shoots than 'Gudrun' $(p<0.05)$. Shoots of 'Tora' were 4.3-5.9 $\mathrm{m}$ and shoots of 'Tordis' $-4.6-6.4 \mathrm{~m}$.

2. $\mathrm{N}_{90}$ and $\mathrm{N}_{120}$ fertilizer rates had the strongest impact on biomass dry matter yield of willows. In 2011, $\mathrm{N}_{60}, \mathrm{~N}_{90}$ and $\mathrm{N}_{120}$ fertilizer rates had stronger effect on the biomass dry matter yield of cultivars 'Tora' and 'Tordis'. $\mathrm{N}_{30}$ and $\mathrm{N}_{60}$ fertilizer rates had greater influence on the biomass dry matter yield of 'Gudrun'. Nitrogen fertilization had significant impact $(p<0.05)$ on the length of shoots of willow, but had no significant impact on the diameter and number of shoots.

3. Biomass dry matter yield of willows, which had been cut after the first growing year (in spring 2006), was greater $(p<0.05)$ than that of not cut willows. In 2006, cut willows developed 4-6 times more shoots than not cut willows. The most intense growth of all willows, which had been cut after the first growing year, was recorded in the second year of cultivation (2006).

4. Maximum biomass dry matter yield was produced in the plots, where willows had been planted in rows when the distance between plants was $0.50 \mathrm{~m}$. The differences were statistically significant not every growing year.

5. It was found that willows intensively grew after the first growing cycle (2005-2008) at the age of 5-7 years (2009-2011) and at the age of 8-10 years (20122014). Their mean annual biomass dry matter yield was the same or higher, compared with the first years of growing: per $1^{\text {st }}$ rotation (2005-2008) - 9.83 $\mathrm{tha}^{-1}$, per $2^{\text {nd }}$ rotation $(2009-2011)-11.2 \mathrm{t} \mathrm{ha}^{-1}$ and per $3^{\text {rd }}$ rotation (2012-2014) - $14.9 \mathrm{t} \mathrm{ha}^{-1}$.

\section{Acknowledgements}

The paper presents research findings, obtained through the long-term research programme "Biopotential and quality of plants for multifunctional use" of Lithuanian Research Centre for Agriculture and Forestry. 


\section{References}

1. Adegbidi H. G., Volk T. A., White E. H., Briggs R. D., Abrahamson L. P., Bickelhaupt D. H. 2001. Biomass and nutrient expert by willow clones in experimental bioenergy plantations in New York. Biomass and Bioenergy, 20 (6): 389-982. https://doi.org/10.1016/S0961-9534(01)00009-5

2. Aylott M. J. Casella E., Tubby I., Street N. R., Smith P., Taylor G. 2008. Yield and spatial supply of bioenergy poplar and willow short-rotation coppice in the UK. New Phytologist, 178 (2): 358-370. https://doi.org/10.1111/j.1469-8137.2008.02396.x

3. Aronsson P., Rosenqvist H., Dimitriou I. 2014. Impact of nitrogen fertilization to short-rotation willow coppice plantations grown in Sweden on yield and economy. BioEnergy Research, 7 (3): 993-1001. https://doi.org/10.1007/s12155-014-9435-7

4. Bakšienè E., Titova J., Nedzinskienė T.-L. 2012 Investigating the possibilities of growing willows (Salix L.) for fuel. Žemès ūkio mokslai, 19 (2): 90-97 (in Lithuanian).

5. Beauchamp S., Jerbi A., Frenette-Dussault C., Pitre F. E., Labrecque M. 2018. Does the origin of cuttings influence yield and phytoextraction potential of willow in a contaminated soil? Ecological Engineering, 111: 125-133. https://doi.org/10.1016/j.ecoleng.2017.11.019

6. Castaño-Díaz M., Barrio-Anta M., Afif-Khouri E., CámaraObregón A. 2018. Willow short rotation coppice trial in a former mining area in northern Spain: effects of clone, fertilization and planting density on yield after five years. Forests, 9: 154.

https://doi.org/10.3390/f9030154

7. Clewer A. G., Scarisbrick D. H. 2001. Practical statistics and experimental design for plant and crop science. Wiley, $346 \mathrm{p}$

8. Cunniff J., Purdy S. J., Barraclough T. J. P., Castle M., Maddison A. L., Jones L. E., Shield I. F., Gregory A. S., Karp A. 2015. High yielding biomass genotypes of willow (Salix spp.) show differences in below ground biomass allocation. Biomass and Bioenergy, 80: 114-127. https://doi.org/10.1016/j.biombioe.2015.04.020

9. Čekanavičius V., Murauskas G., 2003. Statistika ir jos taikymai. 1. Vilnius, Lithuania, 237 p. (in Lithuanian).

10. Čekanavičius V., Murauskas G., 2004. Statistika ir jos taikymai. 2. Vilnius, Lithuania, 272 p. (in Lithuanian).

11. Demo M., Hauptvogl M., Prčik M., Huska D. 2014. Comparison of production parameters of willow (Salix spp.) and poplar (Populus spp.) varieties in the last year of the first four-year harvest cycle. Wood Research, 59 (4): 705-715.

12. Dimitriou I., Aronsson P. 2005. Willows for energy and phytoremediation in Sweden. Unasylva, 56 (221): 47-50.

13. Dimitriou I., Aronsson P. 2010. Landfill leachate treatment with willows and poplars - efficiency and plant response. Waste Management, 30 (11): 2137-2145. https://doi.org/10.1016/j.wasman.2010.06.013

14. Dias G. M., Ayer N. W., Kariyapperuma K., Thevathasan N., Gordon A., Sidders D., Johannesson G. H. 2017. Life cycle assessment of thermal energy production from shortrotation willow biomass in Southern Ontario, Canada. Applied Energy, 204: 343-352. https://doi.org/10.1016/j.apenergy.2017.07.051

15. Hangs R. D., Schoenau J. J., Van Rees K. C. J., Belanger N., Volk T., Jensen T. 2014. First rotation biomass production and nutrient cycling within short-rotation coppice willow plantations in Saskatchewan, Canada. BioEnergy Research, 7 (4) 1091-1111. https://doi.org/10.1007/s12155-014-9452-6

16. Hanley S. J., Karp A. 2013. Genetic strategies for dissecting complex traits in biomass willows (Salix spp.). Tree Physiology, 10: 1-14.
17. Hauptvogl M. 2013. Increase of biomass production of fast-growing willows in the first year of the second harvest cycle. Acta Regionalia et Environmentalica, 2: 34-37. https://doi.org/10.2478/aree-2013-0007

18. Hytönen J., Nurmi J. 2015. Heating value and ash content of intensively managed stands. Wood Research, 60 (1): 71-82.

19. Keoleian G. A., Volk T. A. 2005. Renewable energy from willow biomass crops: life cycle energy, environmental and economic performance. Critical Reviews in Plant Sciences, 24: 385-406. https://doi.org/10.1080/07352680500316334

20. Kuzovkina Y. A., Quigley M. F. 2005. Willows beyond wetlands: uses of Salix L. species for environmental projects. Water, Air and Soil Pollution, 162: 183-204. https://doi.org/10.1007/s11270-005-6272-5

21. Kuzovkina Y. A., Schulthess C. P., Zheng D. 2018. Influence of soil chemical and physical characteristics on willow yield in Connecticut. Biomass and Bioenergy, 108: 297-306.

https://doi.org/10.1016/j.biombioe.2017.11.021

22. Larsen S. U., Jørgensen U., Kjeldsen J. B., Lærke P. E. 2016. Effect of fertilisation on biomass yield, ash and element uptake in SRC willow. Biomass and Bioenergy, 86: $120-128$ https://doi.org/10.1016/j.biombioe.2016.01.014

23. Larsen S. U., Jørgensen U., Lærke P. E. 2018. Biomass yield, nutrient concentration and nutrient uptake by SRC willow cultivars grown on different sites in Denmark. Biomass and Bioenergy, 116: 161-170. https://doi.org/10.1016/j.biombioe.2018.06.011

24. McKendry P. 2002. Energy production from biomass. Part 1: overview of biomass. Bioresource Technology, 83 (1): $37-46$ https://doi.org/10.1016/S0960-8524(01)00118-3

25. Mészáros E., Jakab E., Várhegyi G., Tóvári P. 2007. Thermogravimetry / mass spectrometry analysis of energy crops. Journal of Thermal Analysis and Calorimetry, 88 (2): 477-482.

https://doi.org/10.1007/s10973-006-8102-4

26. Miko P., Kovacs G. P., Alexa L., Balla I., Poti P., Gyurisza C. S. 2014. Biomass production of energy willow under unfavourable field conditions. Applied Ecology and Environmental Research, 12 (1): 1-11. https://doi.org/10.15666/aeer/1201 001011

27. Mirck J., Isebrands J. G., Verwijst T., Ledin S. 2005. Development of short - rotation willow coppice systems for environmental purposes in Sweden. Biomass and Bioenergy, 28 (2): 219-228. https://doi.org/10.1016/j.biombioe.2004.08.012

28. Mola-Yudego B., Gonzáles-Olabarria J.-R. 2010. Mapping the expansion and distribution of willow plantations for bioenergy in Sweden: lessons to be learned about the spread of energy crops. Biomass and Bioenergy, 34 (4): 442-448. https://doi.org/10.1016/j.biombioe.2009.12.008

29. Njakou Djomo S., Kasmioui O. El., De Groote T., Broeckx L. S., Verlinden M. S., Berhongaray G., Fichot R., Zona D., Dillen S. Y., King J. S., Janssens I. A., Ceulemans R. 2013. Energy and climate benefits of bioelectricity from low-input short rotation woody crops on agricultural land over a two-year rotation. Applied Energy, 111: 862-870. https://doi.org/10.1016/j.apenergy.2013.05.017

30. Njakou Djomo S., Zenone A. T., De Groote T., Bergante S., Facciotto G., Sixto H., Ciria Ciria P., Weger J., Ceulemans R. 2015. Energy performances of intensive and extensive short rotation cropping systems for woody biomass production in the EU. Renewable and Sustainable Energy Reviews, 41: 845-854. https://doi.org/10.1016/j.rser.2014.08.058

31. Nordborg M., Berndes G., Dimitriou I., Henriksson A., Mola-Yudego B., Rosenqvist H. 2018. Energy analysis of willow production for bioenergy in Sweden. Renewable and Sustainable Energy Reviews, 93: 473-482. https://doi.org/10.1016/j.rser.2018.05.045 
32. Phillips C. J., Marden M., Suzanne L. M. 2014. Observations of root growth of young poplar and willow planting types. New Zealand Journal of Forestry Science, 44: 1-15. https://doi.org/10.1186/s40490-014-0015-6

33. Raudonius S. 2017. Application of statistics in plant and crop research: important issues. Zemdirbyste-Agriculture, 104 (4): 377-382. https://doi.org/10.13080/z-a.2017.104.048

34. Richards B. K., Stoof C. R., Cary I. J., Woodbury P. B. 2014. Reporting on marginal lands for bioenergy feedstock production: a modest proposal. BioEnergy Research, 7: $1060-1062$. https://doi.org/10.1007/s12155-014-9408-x

35. Šateikis I. 2006. Potential of plant biomass cultivation and use for solid fuels and priority of research the present problems. Agricultural Engineering, 38 (3): 5-21 (in Lithuanian).

36. Sevel L., Nord-Larsen T., Ingerslev M., Jørgensen U., Raulund-Rasmussen K. 2014. Fertilization of SRC willow. I. Biomass production response. BioEnergy Research, 7 (1): 319-328. https://doi.org/10.1007/s12155-013-9371-y
37. Stolarski M. J., Szczukowski S., Tworkowski J., Klasa A. 2008. Productivity of seven clones of willow coppice in annual and quadrennial cutting cycles. Biomass and Bioenergy, 32 (12): 1227-1234. https://doi.org/10.1016/j.biombioe.2008.02.023

38. Stolarski M. J., Krzyżaniak M., Szczukowski S., Tworkowski J., Grygutis J. 2015. Changes of willow biomass quality as a renewable energy feedstock harvested with biobaler. Journal of Elementology, 20 (3): 717-730. https://doi.org/10.5601/jelem.2014.19.3.769

39. Stolarski M. J., Szczukowski S., Tworkowski J., Krzyzaniak M., Załuski D. 2017. Willow biomass and cuttings' production potential over ten successive annual harvests. Biomass and Bioenergy, 105: 230-247. https://doi.org/10.1016/j.biombioe.2017.07.010

40. The productivity of Lithuania's land / compiled by Mažvila J. 2011. Lithuanian Research Centre for Agriculture and Forestry, 280 p. (in Lithuanian).

41. Tubby I., Armstrong A. 2002. Establishment and management of short rotation coppice. Forestry Commission. Practice Note FCPN7, 12 p.

42. WRB. 2014. World reference base for soil resources. World Soil Resources Reports No. 106. FAO, Rome.

ISSN 1392-3196 / e-ISSN 2335-8947

Zemdirbyste-Agriculture, vol. 105, No. 4 (2018), p. 339-348

DOI 10.13080/z-a.2018.105.043

\title{
Auginimo technologijų ịtaka ịvairių veislių gluosnio (Salix spp.) medienos biomasès derliui
}

\author{
E. Bakšienè, J. Titova \\ Lietuvos agrarinių ir miškų mokslų centro Vokès filialas
}

\section{Santrauka}

Didelis susidomėjimas atsinaujinančia energija šiuo metu yra pasaulinė tendencija. Europos Sajungoje akcentuojama biomasès naudojimo svarba ir įvairios plètros galimybès, skatinama augalų biomasę kaip energijos šaltini naudoti vis intensyviau ir kaip galima plačiau. Trumpos rotacijos energiniai augalai (gluosniai, tuopos ir kiti) yra labai perspektyvūs. Tyrimo tikslas - ištirti biomasės sausųjų medžiagų derliaus ir kitų biometrinių rodiklių pokyčius trijų gluosnio (Salix spp.) veisliu 'Tora', 'Tordis' ir 'Gudrun', priklausomai nuo azoto trąšu normu, skirtingo pjovimo dažnio, sodinimo tankumo ir augimo metų. Lauko eksperimentas buvo atliktas 2005-2014 m. LAMMC Vokès filiale, lengvos granuliometrinės sudèties priesmėlio paprastajame išplautžemyje (IDp) Pietryčiu Lietuvos regiono klimatinejje zonoje. $2005 \mathrm{~m}$. pavasarị gluosnių gyvašakès buvo pasodintos 0,65 ir $0,50 \mathrm{~m}$ atstumu eilutèse. Prieš gluosnių sodinimą visas laukas per vieną kartą buvo patręštas mineralinèmis trąšomis $\mathrm{P}_{60} \mathrm{~K}_{80}\left(60 \mathrm{~kg} \mathrm{ha}^{-1} \mathrm{P}_{2} \mathrm{O}_{5}, 80\right.$ $\mathrm{kg} \mathrm{ha}^{-1} \mathrm{~K}_{2} \mathrm{O}$ ). Gegužès mėnesị, kai gluosnių gyvašakès visiškai prigijo, pagal eksperimento schemą per vieną kartą buvo patręšta tokiomis normomis azoto trąšų: $\mathrm{N}_{0}$ (netręšta), $\mathrm{N}_{30}\left(30 \mathrm{~kg} \mathrm{ha}^{-1} \mathrm{~N}\right), \mathrm{N}_{60}\left(60 \mathrm{~kg} \mathrm{ha}^{-1} \mathrm{~N}\right), \mathrm{N}_{90}\left(90 \mathrm{~kg} \mathrm{ha}^{-1}\right.$ $\mathrm{N}), \mathrm{N}_{120}\left(120 \mathrm{~kg} \mathrm{ha}^{-1} \mathrm{~N}\right) .2006,2012,2013$ ir $2014 \mathrm{~m}$. jie buvo tręšti pakartotinai. $2006 \mathrm{~m}$. ankstyvą pavasarị dalis gluosniu buvo nupjauti, kiti palikti augti. Veisliu 'Tora' ir 'Tordis' gluosniai formavo esmingai didesni $(p<0,05)$ biomasės sausųjų medžiagų derlių nei veislès 'Gudrun' augalai. Ilgiausi stiebai buvo veislių 'Tora' ir 'Tordis' gluosnių. Gluosnių biomasès sausujjų medžiagų derliui didžiausią ịtaką turèjo tręšimas $\mathrm{N}_{90}$ ir $\mathrm{N}_{120}$. Tręšimas šiomis normomis trąšų padidino biomasès derlių. Gluosnių, kurie buvo nukirsti po pirmujų auginimo metų (2006 m. pavasarị), biomasės sausųjų medžiagų derlius buvo didesnis nei nenukirstų. Didžiausias biomasès sausųjų medžiagų derlius nustatytas laukeliuose, kuriuose gluosniai buvo pasodinti $0,50 \mathrm{~m}$ atstumu tarp augalų eilutėse.

Reikšminiai žodžiai: biokuras, 'Gudrun', 'Tora', 'Tordis', tręšimas. 